\title{
Vietnamese Accounting Reform and International Convergence of Vietnamese Accounting Standards
}

\author{
Anh Tuan Nguyen ${ }^{1,2}$ \& Guangming Gong ${ }^{1}$ \\ ${ }^{1}$ Business School Hunan University, Changsha, Hunan, China \\ ${ }^{2}$ Faculty of Accounting and Auditing, Ho Chi Minh City University of Industry, Vietnam \\ Correspondence: Anh Tuan Nguyen, Business School Hunan University, Changsha, Hunan 410082, China. Tel: \\ 86-151-1649-6596. E-mail: tuanqn1974@gmail.com
}

Received: February 22, 2012 Accepted: April 16, 2012 Online Published: May 16, 2012

doi:10.5539/ijbm.v7n10p26

URL: http://dx.doi.org/ijbm.v7n10p26

\begin{abstract}
Due to the economic globalization, the international convergence of accounting standards is inevitable. But the level of economic globalization in among of countries are not the same. There are some differences in accounting environment in the countries. This paper studies international convergence of Vietnamese accounting standards. Firstly, the paper summarizes of the process of Vietnam's accounting reform, second analysis differences between Vietnamese accounting standards and International accounting standards. Finally, proposed strategy convergence of Vietnamese accounting standards and International accounting standards.
\end{abstract}

Keywords: international convergence, Vietnamese Accounting Standards (VAS), International Accounting Standards (IAS), International Financial Reporting Standards (IFRS), accounting reform

\section{Introduction}

According to globalization of capital markets has a major impact on the international convergence of accounting standards. Recently, there have been considerable efforts to achieve international convergence of accounting by reducing cross-country differences in accounting practice. Among the efforts of international convergence of accounting standards, the International Accounting Standards Board (IASB) (Note 1) has played an important role, with aims of the development of a single set of high quality global accounting standards that's International Financial Reporting Standards (IFRS). From 2005 many world countries adopted IFRS, firstly is European Union (EU), followed is Australia and NewZealand, etc. Up to date, approximately 117 countries around the world require or permit IFRS reporting for domestic, listed companies (Note 2). However, a few countries are slower convergence with IFRS; these countries are still debating the overall benefits of full IFRS adoption. Since 2001 Vietnam has established Vietnamese accounting standards system based on International Accounting standards system. In general, there is still difference between Vietnamese accounting standards with International accounting standards. However, the process of accounting reform in Vietnam entered into a new phase that is slowly converging Vietnamese accounting standards to International accounting standards and International financial reporting standards (IAS/IFRS).

\section{Overview of Vietnamese Accounting Reform}

In 1986, the sixth Congress of the Communist Party of Vietnam. Vietnam declared the construction of socialist orientation of market economy and initiated a comprehensive reform, Vietnamese accounting field has also undergone a series of profound changes. Throughout the developing process of Vietnamese accounting based on economic reform and opening-up policy implementation as the basic background conditions. The Vietnamese accounting reform can be divided into three major periods:

\subsection{Period 1 (1981-1990)}

At the beginning of the 1980s, accounting reform bring the private sector has officially granted a position in the economy. Vietnam Ministry of Finance issued an accounting regulation, even though still simple for private enterprises, known as the Decision 278/QD/CDKT (10/3/1981) "Accounting Policy for Industrial and commercial Business Private Enterprises". Then due to rapid growth of the private sector, the Ministry of Finance had to introduce (issue) more complete accounting policies to regulate the accounting activities of that sector, that is, Decision 229/QD/CDKT (12/1988) “Accounting Policy for Individual household business and 
Private Business" and Decision 598/QD/CDKT (12/1990) "Accounting Policy for non-State owned enterprise". An important event in this period was the introduction of the "Ordinance on Accounting and Statistics" in 1988. This is the highest legal document on accounting.

Following the economic reform, on March 18th 1989, the Government published Decree no 25/HDBT "Regulation on Organising of State Accounting" and Decree no 26/HDBT "Regulation on Chief Accountant of State-Owned Enterprise". A new chart of accounts and new accounting reports were introduced through Decision 212/QD/CDKT (15/12/1989) and Decision 224/QD/CDKT (18/4/1990) respectively. In general the accounting reforms in this period were not radical so that the accounting system primary to serve planning economy.

\subsection{Period 2 (1991-1995)}

Innovation policy in this period towards the restructuring of state-owned enterprise began decree no 338/HDBT $(11 / 20 / 1991)$, to reduce the number of state-owned enterprises, and improve the quality of its activities. Besides, the other economic sectors also strong development during this period contributed to a market economy more fully than the previous period. This creates a pressure to reform the Vietnamese accounting system to meet the stage of development of market economy in Vietnam.

Under the direct supervision of Prime minister, the Ministry of Finance directed to complete thoroughly accounting reform, covering all elements of accounting and auditing. The Ministry of Finance had mobilised a vast number of accounting experts including academics, accounting policy makers, professional accountants from public accounting and auditing firms, accountants from big state-owned enterprise, and former accounting experts from the South to take part in the accounting reform. In 1995, the Ministry of Finance published a unified chart of accounts (Decision 1141-TC/QD/CDKT, adopted on January 1st, 1995, and effective on January 1st, 1996). In 1994, establishment of the Vietnam Accounting Association (VAA) (Decision 12/TTg 10/01/1994) marked a new important element in the accounting mechanism.

In summary, the accounting regulation issued in this period illustrated the high initiative and effort of the government to radically reform the Vietnamese accounting system. Regarded as an important tool for management, accounting has been renovated to satisfy the information need of an emerging market economy with socialist orientation.

\subsection{Period 3 (from 1996 until Present)}

This period marked a more critical change in the Vietnamese accounting system. The Government, faced with increasing pressures from foreign investors and international financial institutions, such as the World Bank (WB), the Asian Development Bank (ADB) and the International Monetary Fund (IMF), and preparing for the opening of the Vietnamese stock market, committed itself to undertake more vital reform in accounting.

A European Union assistance project, named the European Commission's Technical Assistance Program for Transition to Market Economy in Vietnam (EURO-TapViet), began from September 1995 and finish August 1998. This project has helped Vietnam's leaders understand the international accounting practices and equip certain of knowledge on accounting and auditing of market economy.

With the help of the European Union (EU), in 1996, Vietnam Accounting Association (VAA) successfully organized international conference on accounting with the participation of 160 representatives from professional associations, such as the International Federation of Accountants (IFAC), the European Accounting Association (EAA), the Confederation of Asian and Pacific Accountants (CAPA), the ASEAN Federation of Accountants (AFA) and professional associations in many countries around the world. Also this year the Vietnam Accounting Association (VAA) has been accepted as a member of International Federation of Accountants (IFAC). In 1998 was a member of ASEAN Federation of Accountants (AFA). This event marks an important step in the integration process of the international accounting.

The development of Vietnamese accounting standards was considered to be the best way to make the accounting system achieve greater conformity with international accounting practice. The construction of Vietnamese accounting standards (VAS) on the basis of International Accounting Standards (IAS) and compatibility with the development of Vietnam's economy market and Vietnamese accountancy experience, proficiency and practice. The effort of formulation and promulgation of VAS, on December 31st, 2001, the Ministry of Finance published the first four accounting standards, then issued six others in 2002. To date, the Vietnamese Ministry of Finance has already issued 26 accounting standards, are issued in five phases (see Table 1).

In 2003, the Vietnamese government replaced the ordinance on Accounting and Statistics with the Accounting law. The Accounting Law has marked a critical point in accounting change because it has recognised the importance of accounting in the Vietnamese transition economy by improving its legal status. The Accounting 
Law was built on a number of bases including a reference to accounting laws of other countries, experience learned in the period of applying the ordinance on Accounting and Statistics, in correspondence with other laws and regulations and the reality of accounting practice in Vietnam. It aims "to uniformly regulate accounting to ensure that accounting is an effective and strict tool in managing economic and financial activities, and to provide complete, true, transparent and in-time information that satisfy the information needs of government authorities, enterprises and individuals in administration and management".

Table 1. The Vietnamese Accounting Standards

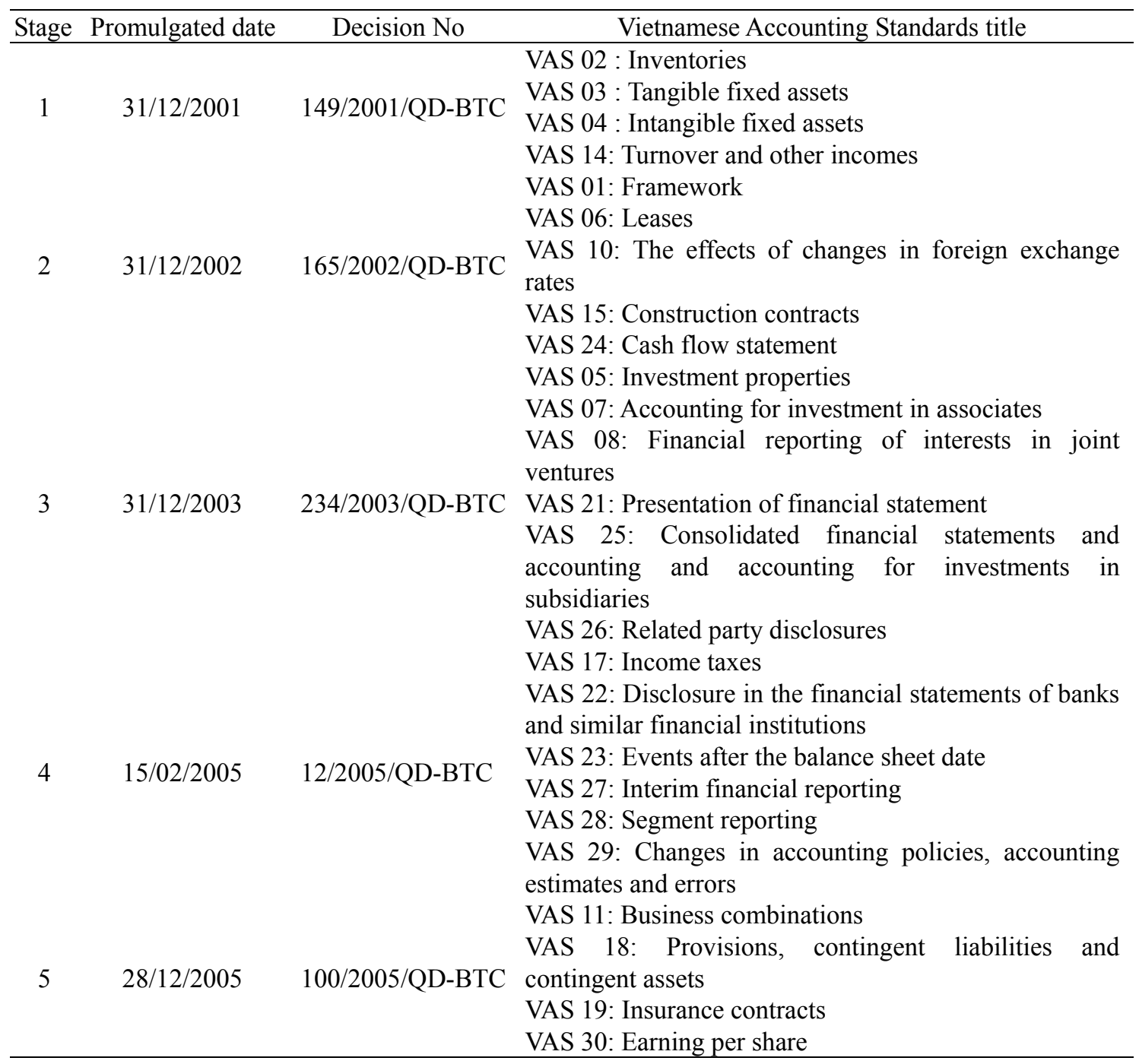

After 26 accounting standards were issued and the accounting law were published, the Ministry of Finance to amend the enterprise accounting system to be in line with accounting standards. On March 20th 2006, the Ministry of Finance published the new enterprise accounting system (Decision 15/2006/QD-BTC/CDKT) replaced (Decision 1141-TC/QD/CDKT).

This period with the promulgation and application of Vietnamese accounting standards system has significantly contributed in the improvement of legal framework on accounting and enhance the transparency of financial information and create business environment in accordance with regional and international, to maintain confidence for foreign investors in Vietnam.

\section{The Differences of Vietnamese Accounting Standards and IAS/IFRS}

The Vietnamese accounting standards is based on IAS with adjustments for economic, finance and accounting Vietnam's conditions. However, there are still differences between Vietnamese Accounting Standards (VAS) and International Accounting Standards and International Financial Reporting Standards (IAS/IFRS). The 
summarized on these differences is as follows:

First of all, Vietnam's accounting standards and accounting system in parallel implementation, this approach differs of most countries and not conducive to the development of Vietnam's accounting standards and international convergence of accounting standards. Secondly, Vietnamese accounting standards structure consists of the basic standard and specific standards (Note 3). VAS01 "Framework" is a standard, not separated as IASB framework so that VAS01"Framework" doesn't plays role equivalent to an IASB Framework, although the purposes set out similar to the IASB framework. The principle of "Substance for from", an important feature principle-based international standards. Thirdly, Vietnamese accounting standards less flexible than IAS, regulations not enough detailte, some new problems have not yet involved, such as financial instrument, impairment of assets, ect. Furthermore, in the specific accounting treatment and disclosure requirements, Vietnamese accounting standards with international accounting standards also there are many differences (see Table 2).

Table 2. Main differences between Vietnamese Accounting Standards (VAS) and International Financial Reporting Standards (IAS/IFRS)

\begin{tabular}{|c|c|c|}
\hline IAS/IFRS and VAS & Current status & VAS differences from IAS/IFRS \\
\hline $\begin{array}{l}\text { IAS1 Presentation of Financial } \\
\text { Statements }\end{array}$ & \multirow{3}{*}{$\begin{array}{l}\text { VAS } 21 \text { is based } \\
\text { on the previous } \\
\text { version of IAS } 1 \\
(2003)\end{array}$} & $\begin{array}{l}\text { - VAS } 21 \text { does not require disclosure of management's } \\
\text { key judgments, key assumptions concerning the future } \\
\text { and other key sources of estimation uncertainty; }\end{array}$ \\
\hline \multirow{2}{*}{$\begin{array}{l}\text { VAS21 Presentation of } \\
\text { Financial Statements }\end{array}$} & & $\begin{array}{l}\text { - VAS } 21 \text { requires an analysis of changes in equity in the } \\
\text { notes to the financial statements rather than as a primary } \\
\text { statement. }\end{array}$ \\
\hline & & $\begin{array}{l}\text { - Information to be presented on the face of the balance } \\
\text { sheet and income statements are based on the standard } \\
\text { VAS financial statement format. }\end{array}$ \\
\hline
\end{tabular}

In addition to the above differences, companies reporting under VAS are also required to apply the VAS chart of accounts and standard financial statements format, prescribed by Decision 15/2006-QĐ-BTC issued by the Ministry of Finance, which are descriptive and inflexible. Therefore, financial statements prepared under VAS may have various classification and presentational differences compared to financial statements prepared under IFRS.

IAS2 Inventories and VAS02 Inventories

IAS7 Cash Flow Statements

VAS24 Cash Flow Statements

IAS8 Accounting Policies, Changes in Accounting

Estimated and Errors

VAS29 Changes in Accounting Policies, Accounting Estimated and Errors
VAS 02 is based on the previous version of IAS 2

VAS24 is based on the previous version of IAS 7

Fully Implemented
Estimation techniques such as standard cost and the retail method are not permitted under VAS; FIFO, LIFO, specific identification and weighted average methods are all accepted. However, if LIFO method is used, disclosure of the effect of using LIFO in comparison to FIFO or weighted average is required.

There are no significant differences 
IAS10 Events after the Reporting Period VAS23 Events after the Balance Sheet date
IAS11 Construction Contracts VAS15 Construction Contracts IAS12 Income Taxes VAS17 Income Taxes

IAS16 Property, Plant and Equipment VAS03 Tangible Fixed Assets
VAS23 is based on the version of IAS10 (amended 2005)
Fully Implemented Fully Implemented

- While IAS 10 provides guidance on the determination of the date the financial statements are authorized for issue which will vary depending upon the management structure, statutory requirements and procedures to follow in preparing and finalizing the financial statements, VAS 23 is silent on this.

- VAS 23 specifically states that the issuing date is the date when the head of the reporting entity (or an authorized person) authorizes the issue of the financial statements to outsiders. IAS 10 does not have such specific guidance.

- VAS 15 is similar to IAS 11 except for the following additional guidance in VAS 15

VAS 17 is similar to IAS 12 except that:

- VAS 17 does not address temporary differences and deferred tax recognition, in respect of:

+ Business Combinations

+ Goodwill

+ Asset carried at fair value

+ Government grants

- Definition of income tax under VAS 17 includes Business Income Tax being withheld on payments to overseas service providers in accordance with Business Income Tax law.

VAS 03 is based on the previous version of IAS 16 (amended in 2005)

- Property, plant and equipment should be carried at cost less depreciation. Revaluation of Property, Plant and Equipment is not allowed unless specific approval is obtained from the Government. VAS 03 does not include within its scope the measurement and recognition of asset dismantlement, removal and restoration costs. In determining the cost of an item of Property, Plant and Equipment VAS 03 only includes the costs incurred as a consequence of installing the item.

- IAS 16 requires an entity to measure an item of Property, Plant and Equipment acquired in exchange for a non-monetary asset or assets, or a combination of monetary and non-monetary assets, at fair value unless (a) the exchange transaction lacks commercial substance or (b) the fair value of neither the asset received nor the asset given up is reliably measurable. IAS 16 requires companies to first look at the fair value of the asset received in measuring the value of the transaction. Under VAS 03, an entity measures such an acquired asset at fair value of either the asset received or given up, adjusted by any cash received or paid. Where the exchanged assets were similar and had similar fair values, the carrying amount of the asset given up is used as the cost of the new asset, even if the fair value of these assets can be reliably determined.

- Impairment write down of Property, Plant and Equipment is not allowed under VAS 03 unless specific approval is obtained from the Government.

VAS 06 is based on the previous version of IAS 17
VAS 06 is similar to IAS 17 except that VAS 06 dose not provide guidance for accounting for revenue by manufacture or dealer lessors. 


\section{IAS 18 Revenue}

VAS 14 Turnover and other

Income

IAS19 Employee Benefits

No Effective VAS

IAS20 Accounting for

Government Grants and

Disclosure of Government

Assistance

No Effective VAS

IAS21 The Effect of Changes in Foreign Exchange Rates

VAS10 The Effects of Changes in foreign Exchange

Rates

IAS23 Borrowing Costs VAS16 Borrowing Costs

IAS24 Related Party

Disclosures

VAS26 Related Party

Disclosures

IAS26 Accounting and

Reporting by Retirement

Benefit Plans

No Effective VAS

IAS27 Consolidated and

Separate Financial Statement

VAS25 Consolidated

Financial Statement and

Accounting for Investment in

Subsidiaries
VAS 14 is based

on the previous version of IAS 18

No Effective VAS

No Effective VAS

- VAS 14 provides a specific guidance on what should be considered as other income.

No existing VAS which is equivalent to IAS 19

VAS 10 is based on the previous version of IAS 21 (1993)

VAS 16 is based on IAS 23

VAS26 is based on the previous version of IAS24

No Effective VAS

VAS 25 is based on the previous version of IAS 27
- Current IAS 21 requires each individual entity included in the reporting entity whether it is a stand-alone entity, an entity with foreign operations (such as a parent) or a foreign operation (such as a subsidiary or branch) to determine its functional currency and measure its results and financial position in that currency. VAS 10 does not include a requirement to determine "functional currency".

- VAS 16 is similar to IAS 23 except that VAS16 requires capitalisation of borrowing costs which are directly attributable to qualifying assets. In contrast, IAS 23 allows entities to elect as an accounting policy choice whether to capitalise or expense off immediately such borrowing costs

The definition of related party under IAS 24 has been expanded to;

- parties with joint control over the entity

- joint ventures in which the entity is venture; and

- post-employment benefit plans for the benefit of employees of an entity, or of any entity that is a related party to that entity.

IAS 24 adds a definition of "close members of the family of an individual" and clarifies that non-executive directors are key management personal.

No existing VAS which is equivalent to IAS 26

- Under IAS 27, investments in subsidiaries in the parent's separate financial statements can be carried at cost or as a financial asset in accordance with IAS 39. VAS 25 only allows such investments to be carried at cost in the parent's separate financial statements.

- Under VAS, a parent is exempted from preparing consolidated financial statements if the parent is a wholly-owned subsidiary, or is virtually wholly-owned, provided in the case of one that is virtually wholly-owned, the parent obtains the approval of the owners of the minority interest. More conditions must be met under IAS 27 before this exemption is permitted.

- VAS 27 allows a subsidiary to be excluded from consolidation when it operates under severe long-term restrictions which significantly impair its ability to transfer funds to the parent. IAS 27 does not contain such exemption. 
IAS28 Investment in

Associated

VAS07 Accounting for

Investment in Associates

IAS 29 Financial Reporting in Hyperinflationary Economics

No Effective VAS

IAS 31 Interest in Joint

Ventures

VAS08 Financial Reporting

of Interest in Joint Ventures
VAS 07 is based on the previous version of IAS 28

No Effective VAS

VAS 08 is based on the previous version of IAS 31

No Effective VAS

IAS32 Financial Instrument: Presentation

No Effective VAS

IAS33 Earnings per Share

VAS30 Earnings per share

IAS34 Interim Financial

Reporting

VAS27 Interim Financial

Reporting

IAS36 Impairment of Assets

No Effective VAS

IAS37 Provisions, Contingent

Liabilities and Contingent

Assets

VAS18 Provisions,

Contingent Liabilities and

Contingent Assets

IAS 38 Intangible Assets VAS04 Intangible Fixed Assets

Fully Implemented

Fully Implemented

VAS 04 is based version of IAS 38
- Investment in an associate is not subject to impairment testing under VAS 07.

- Investment in an associate that meets the held for sale criteria must be classified as non-current asset held for sale in accordance with IFRS 5. Under VAS, such investment must be classified as investment in an associate until it is sold or disposed.

- Under IAS 28, investments in associates in the investor's separate financial statements can be carried at cost or as a financial asset in accordance with IAS 39. VAS 07 requires such investments to be carried at cost if the investor does not have a subsidiary and does not prepare consolidated financial statements.

No existing VAS which is equivalent to IAS 29

- VAS 08 includes Vietnam-specific references such as Business Co-operation Contracts;

- Proportionate consolidation method is not allowed under VAS 08;

- Under IAS 31, a venturer accounts for its interest in a jointly controlled entity in its separate financial statements at cost. IAS 31 allows such investments to be carried at cost or as financial assets in accordance with IAS 39.

- IAS 31 requires that a venturer must account for its interest using equity method regardless of whether consolidated financial statements are prepared. There is no clear guidance in VAS 08 . In practice, companies that only prepare separate financial statements account for their investment in joint ventures at cost.

No existing VAS which is equivalent to IAS 32

VAS 27 is similar to the current version of IAS 34 except VAS 27 specifically states that VAS 27 is applicable for enterprises which are required by law to prepare quarterly financial statements or which voluntarily prepare interim financial statements.

No Effective VAS No existing VAS which is equivalent to IAS 36

Fully Implemented VAS 18 is similar to IAS 37 except IAS 37 states that in the case where it is not clear whether a present obligation exists, a past event is deemed to give rise to a present obligation if, taking account of all available evidence, it is more likely than not that a present obligation exists at the balance sheet date. In contrast, VAS 18 recognition criteria for such event is based on "certain" threshold which is likely to be a different threshold from "more likely that not" under IAS 37. - Intangible assets recognised in accordance with VAS on the previous 04 must be amortised over a useful life of no longer than
20 years, unless there is persuasive evidence that a life over 20 years is appropriate;

- Under VAS, intangible assets must be recognised at cost less accumulated amortisation. Revaluation or write down for impairment is not allowed. 
IAS39 Financial Instruments: No Effective VAS Recognition and

Measurement

No Effective VAS

IAS40 Investment Property

VAS05 Investment Properties

IAS41 Agriculture

No Effective VAS

IFRS1 First-time Adoption of

International Financial

Reporting Standards

No Effective VAS

IFRS2 Share-based Payment

No Effective VAS

IFRS3 Business

Combinations

VAS11 Business

Combinations

IFRS4 Insurance Contracts

VAS19 Insurance Contracts

IFRS5 Non-Current Assets

held for Sale and

Discontinued Operation

No Effective VAS

IFRS6 Exploration for and

Evaluation of Mineral

Resources

No Effective VAS

IFRS7 Financial Instruments

No Effective VAS

IFRS8 Operating Segments

No Effective VAS

IFRS9 Financial Instruments

No Effective VAS

Fully Implement

No Effective VAS

No Effective VAS

No Effective VAS on IFRS3

Fully Implement

No Effective VAS

No Effective VAS

- Certain pre-operating costs, in relation to an entity's establishment, training, advertisement activities, research and relocation of a business are allowed to be deferred and charged to income statement over 3 years under VAS.

No existing VAS which is equivalent to IAS 39

VAS11 is based

No existing VAS which is equivalent to IFRS6

No existing VAS which is equivalent to IFRS7.

VAS22 Disclosures in the Financial Statement of Bank and similar Financial Institutions. It applies only to banks and Financial Institutions.

No existing VAS which is equivalent to IFRS8.

VAS28 Segment Reporting similar the previous version of IAS 14

No Effective VAS No existing VAS which is equivalent to IFRS 9

VAS 05 is similar to IAS 40 except fair value measurement is prohibited under VAS 05. Investment property can only be carried at cost less accumulated depreciation.

No existing VAS which is equivalent to IFRS 1

No existing VAS which is equivalent to IFRS 2

- Goodwill is amortised over its estimated useful life of - Goodwill is not subject to mandatory annual Gairment review. Instruments: Disclosures, which are not reflected VAS19.

does not requires a disclosure of information on - a sensitivity analysis that shows how profit or loss and equity would have been affected had changes in the relevant risk variable that were reasonably possible at the balance sheet date occurred; the methods and 作 methods and assumptions used;

- qualitative information about sensitivity, and information about those terms and conditions of cash flows

No existing VAS which is equivalent to IFRS5 


\section{Causes of the Difference between Vietnamese Accounting Standards and IAS/IFRS}

\subsection{Economic Environment}

Economic environment is a major element influencing the international convergence of Vietnamese accounting standards. Socialist market economy in Vietnam is still in the primary stage of development, market economic system is not perfect, business legal system are not perfect, the law did not keep up with the business transactions. Vietnam's capital market scale is relatively small (Note 4) and only in the domestic area and not connected with the world's capital market. In addition the State-owned enterprise property right regime is not perfect, internal structure is weak, the lack of effective supervision mechanism of State-owned enterprises.

\subsection{Legal Environment}

In Vietnam, the government intervenes considerably in accounting standards setting. The Accounting Standards Board (ASB) was established by Minister of Finance. Vietnam Accounting Standards Board is responsibility of establishing the Vietnamese Accounting Standards. The Board consist 13 members are not government officers but not completely independent from the government. The Vietnamese Accounting Association (VAA) does not play an active role setting accounting standards. The Accounting Policy Department of the Ministry of Finance is responsible for these tasks.

Vietnam is a country according the code law system, however most western countries belong to the common law system. The code law countries, in general shareholder protection and transparency requirements of the information are lower than in common law countries (Y. Ding et al. 2007). International accounting standards are setting in accordance with the legal system and the requirements of the common law countries. Vietnamese accounting standards are constructed in accordance with the legal system and the requirements of the according code law country. The Vietnamese accounting system is strictly regulated by law, from laws on accounting (the highest hierarchical level) to circulars (the lowest hierarchical level).

\subsection{Cultural Environment}

Since 1980s, many studies confirm that the cultural factors influence the development of accounting. The cultural characteristics differences between countries have created much different accounting system. For example, the cultures Anglo-Saxon countries, tend to flexibility and accounting judgments. Conversely eastern countries tend to more stringent regulations. According Hofstede's four cultural factors measure the similarities and differences in culture between countries on the world: Power distance (PDI), Individualism (IDV), Uncertainty avoidance (UAI), Long-term Orientation (LTO). These factors influence the development of accounting and the changes of accounting system.

The below Table 3 clearly shows the cultural differences between Vietnam and Anglo-Saxon countries (Note 5). Vietnam is a large power distance and collectivist country. Hence, Vietnam's accounting system tends to strict rules and a unified, is often limited to the disclosure of accounting information, accounting statements. More conservative Collectivist cultural characteristics do not benefit sufficiently reliable information disclosure.

Table 3. Comparison of some cultural values between Vietnam and Anglo-Saxon countries

\begin{tabular}{lcccc}
\hline Country & $\begin{array}{c}\text { Power Distance } \\
\text { (PDI) }\end{array}$ & $\begin{array}{c}\text { Individualism } \\
\text { (IDV) }\end{array}$ & $\begin{array}{c}\text { Uncertainty } \\
\text { Avoidance (UAI) }\end{array}$ & $\begin{array}{c}\text { Long-term } \\
\text { Orientation (LTO) }\end{array}$ \\
\hline Vietnam & 70 & 20 & 30 & 80 \\
United States & 40 & 91 & 46 & 29 \\
United Kingdom & 35 & 89 & 35 & 25 \\
Australia & 36 & 90 & 51 & 31 \\
New Zealand & 22 & 79 & 49 & 30 \\
Canada & 39 & 80 & 48 & 23 \\
\hline
\end{tabular}

Source: Geert Hofstede

\subsection{Staff Quality}

Vietnam has recognized the importance of the professional organizations, contribute to run accounting and auditing of activities, promote professional specialization. With the policy of development of system provider service of accounting and auditing, to date, in Vietnam there are total of more than 7,000 accountants professional. However, Vietnamese accountants' professional quality is not high, and lack in necessary 
professional judgment ability. Moreover, in the recent years international accounting system has constant changes, they have no enough time to absorb and grasp these new knowledge. Therefore, this is a large challenge for Vietnam in the process of convergence with international accounting standards system.

\section{Suggest Strategy Convergence of Vietnamese Accounting Standards with IAS/IFRS}

\subsection{Purpose Convergence with International Accounting}

Due to the development of Vietnam's stock market and the enterprises operating in several fields such as banking, insurance, etc requires Vietnam needs to a set of high quality accounting standards based on IFRS and ensure compliance to protection the interests investors and other stakeholders. Beside, the current conditions of Vietnam is not compatible with full IFRS adoption. Therefore, a gradual convergence with IFRS may be more suitable for Vietnam. The immediate goal is just convergence for listed companies, the enterprises operating in several fields such as bank, insurance and consolidated financial statements. For the remaining enterprises, will continue to apply Vietnamese accounting standards but is adjusted the gap towards narrowing with IFRS. Maintains chart of accounts uniform, but increased flexibility to help the enterprises have an advantage when apply IFRS.

\subsection{Roadmap for Convergence of Vietnamese Accounting Standards with IAS/IFRS}

Roadmap can stretches for many years with many different stages, each stage can be proposed as follows:

Stage I: Improve the business legal system; update and amend the accounting standards issued.

Stage II: Continue to promulgate the new accounting standards based on IAS/IFRS

Stage III: Implementation convergence with IFRS for listed companies, the enterprises operating in several fields such as banking, insurance and others enterprises have consolidated financial statements.

\subsection{Solution Strategy Convergence of Vietnamese Accounting Standards with IAS/IFRS}

\subsubsection{Continue to Improve of Vietnamese Accounting Standards}

Continue to review and improve the content of the accounting standards issued, amend and additional the points are not consistent with IFRS. Due to Vietnamese accounting standards is based IAS issued up through 2003, to date the Vietnamese accounting standards not changed to reflect amendments to IFRS. Continue to promulgate Vietnamese accounting standards needed for the development and integration of the economy including standards such as Standard No. 32-Financial instrument; Standard No. 36-Impairment of assets; Standard No. 41-Agriculture; Standard No. 39-Recognition and measurement financial information, etc,...these standards are difficult standards and not popular in Vietnam. Therefore, the drafting process should proceed step by step, in a certain period of sufficient to understand the content of IAS and determine how to apply in Vietnam.

\subsubsection{The Improving of Capacity for Team Accountants}

International accounting standards IAS/IFRS is considered to be very complex, even at countries with developed economics. Vietnamese Accountants will encounter new accounting concepts and new accounting treatment methods not in the Vietnamese accounting system. Moreover, accounting treatment method of transactions according to international accounting standards IAS/IFRS based on the nature of the transaction, hence requires accountants is sufficient to make judgment and estimates. Therefore, Vietnam needs to develop a team of professional accountants of professional level and professional ethics, in order to achieve recognition of the region and international. Combined training of professional accountants in the country and abroad, not only universities but also through professional organizations. In addition, we should learn from international experiences in accounting training, promote the international harmonization of further accounting training.

\subsubsection{Improve and Construction of Mechanism Promulgation Vietnamese Accounting Standards}

Need construction Vietnam Accounting Standards Board (VASB) in charge of drafted accounting standards for submission to the Finance Ministry issued. Based on international experience (such as United Kingdom and United States) and the specific situation of Vietnam, VASB should be established four additional institutions as follows:

1) Accounting Standards Advisory Committee have the responsibility to establish a strategy, plans and solution improving the accounting and auditing system.

2) Accounting standards drafting Committee have the responsibility organize researching and drafting accounting standards for submission to Accounting Standard Board.

3) Accounting Standards Guidelines Committee have responsible for issuing guidelines for accounting standards. 
4) Audit committee have the responsibility to participate in the assessment and processing of disputes on accounting and auditing.

\section{Conclusion}

When formulation of Vietnamese accounting standards (VAS), the perspective is compliance with International financial reporting standards (IFRS), however, Vietnamese accounting standards system still different from international accounting, because only use the contents in accordance with actual conditions in Vietnam; in accordance with the level of economic development, the political regime, legal system, cultural, social; accordance with the level of Vietnamese accountants. These differences are only temporary and increasingly narrow the Vietnamese economic of development to higher level and Vietnamese accountants' professional quality better. Vietnamese accounting standards (VAS) will continue to improve height level, more consistent with IFRS.

\section{References}

Boka, Moussa. (2010). On the International convergence of Accounting standards. International Journal of Business and Management, 5, 89-92. http://www.ccsenet.org/journal/index.php/ijbm/article/view/5180/4613

Đặng Thái Hùng. (2008). Hệ thống chuẩn mực kế toán Việt Nam: Định hướng hoàn thiện trong thời gian tới/Vietnamese accounting standards system: Orientation in the future complete in the next period. Accounting Journal, 71, 7-11. Retrieved from http://www.tapchiketoan.com/ke-toan/

David, C. Y., \& Anh Thuc Nguyen. (2003). The enterprise accounting system of Vietnam and United States generally accepted accounting principles: A comparison. Advances in International Accounting, 16, 175-204. Retrieved from http://www.sciencedirect.com/science/article/pii/S0897366003160102

Đoàn Xuân Tiên. (2008). Hệ thống chuẩn mực kế toán Việt Nam: Những vấn đề tiếp tục hoàn thiện / Vietnamese accounting standards system: These issues shoul continue to improve. Accounting Journal, 6, 38-41. Retrieved from http://www.tapchiketoan.com/ke-toan/

Hongman Zhang. (2010). On the Construction of China's Accounting Standard system with International Convergence in Accounting Standards. International Journal of Business and Management, 4, 200-203. Retrieved from http://www.ccsenet.org/journal/index.php/ijbm/article/view/5698/4625

Narayan F. B., \& Godden, T. (2000). Financial Management and Governance Issues in Vietnam. Retrieved from http://www.adb.org/Documents/Books/Financial_Mgt/Vietnam/prelims.pdf

Price water house Coopers. (2008). Similarities and differences a comparison of IFRS and Thai GAAP, Vietnamese GAAP, Cambodian GAAP and Laos GAAP. Retrieved from $\mathrm{http} / / / \mathrm{www} . p w c . c o m / e n \_V N / v n /$ publications/assets/similarities_and_differences_gaap.pdf

Thanh Chu. (2004). Accounting changes in a transition economy: The case of Vietnam. Retrieved from http://ro.uow.edu.au/theses/1903/

Y. Ding et al. (2007). Diffrences between domestic accounting standards and IAS: Measurement determinants and implication. Journal of Accounting and Public Policy, 26, 1-38. http://dx.doi.org/10.1016/j.jaccpubpol.2006.11.001

\section{Notes}

Note 1. The International Accounting Standards Board (IASB) established by the International Accounting Standards Committee (IASC).

Note 2. Data from the International Accounting Firm Deloitte IFRS professional website: http://www.iasplus.com/country/useias.htm\#totals (accessed November 22, 2011).

Note 3. During the period 2001-2005 Vietnam issued basic standard (VAS01: Framework) and 25 specific standards.

Note 4. The first stock market - Ho Chi Minh City Securities Trading Center HoSTC launched in 2000 with only two listed firms (upgraded to Ho Chi Minh Stock Exchange HOSE in August 2007). The second stock market Hanoi Securities Trading Center (HASTC) is subsequently established in 2005. The numbers of listed firms by the end of 2009, there are over 400 listed firms. The total market capitalization accumulated up to $\$ 620$ trillion VND (\$30.6 billion USD), which equals nearly 38 percent of total GDP (State Securities Commission of Vietnam 2010).

Note 5. Geert Hofstede. See http://greert-hofstede.com/vietnam.html (accessed November 28, 2011). 